Accepted refereed manuscript of:

McMillan D \& McMillan F (2017) The interaction between risk, return-risk trade-off and complexity: Evidence and policy implications for US bank holding companies, Journal of International Financial Markets, Institutions and Money, 47, pp. 103-113.

DOI: $10.1016 /$ j.intfin.2016.11.004

(C) 2017, Elsevier. Licensed under the Creative Commons AttributionNonCommercial-NoDerivatives 4.0 International http://creativecommons.org/licenses/by-nc-nd/4.0/ 


\title{
The Interaction between Risk, Return-Risk Trade-off and Complexity: Evidence and Policy Implications for US Bank Holding Companies
}

\author{
David G. McMillan \\ Accounting and Finance Division \\ Stirling Management School \\ University of Stirling \\ Fiona J. McMillan \\ Business School \\ University of Dundee
}

April 2015

\begin{abstract}
$\underline{\text { Abstract }}$
This paper examines two aspects of bank risk with a particular emphasis on examining the interaction between them. Moreover, throughout the analysis we differentiate between non-complex and complex banks, the latter of which could be seen as holding a further level of risk. We wish to establish how these risk behaviours interact with bank specific, market structure and economic factors. Key results indicate that earnings volatility (business risk) increases with market power but decrease with size and output. While risk-taking (managerial risk) decreases with market power and increases with size and output. Furthermore, in examining return per unit of risk, results demonstrate that increase return and risk-taking is associated with bank specific factors and the economic environment, whereas decreased risk taking is associated with market structure. This suggests a management of risk, which increases around factors under bank control or improving external environment but decreases with the interaction of competitors. Overall, the results suggest that policy should focus on liquidity and equity buffers that should operate countercyclicality but size and market structure per se are not determining factors for higher risk. In terms of the recent financial crisis, it is likely that the great moderation that proceeded it lead to higher risk-taking due to higher economic growth but without the necessary buffers being built up.
\end{abstract}

Keywords: Banks, Risk, Earnings, Volatility, Risk-Return, Complex, Prospect Theory, Market Structure, Sharpe Ratio JEL: C23, G21

Address for Correspondence: Professor David McMillan, Accounting and Finance Division, Stirling Management School, University of Stirling, FK9 4LA, Scotland, UK Phone: +44(0)1786-467309; Fax: +44(0)1786-467308

E-mail: david.mcmillan@stir.ac.uk 


\title{
The Interaction between Risk, Return-Risk Trade-off and Complexity: Evidence and Policy Implications for US Bank Holding Companies
}

\author{
April 2015
}

\begin{abstract}
$\underline{\text { Abstract }}$
This paper examines two aspects of bank risk with a particular emphasis on examining the interaction between them. Moreover, throughout the analysis we differentiate between non-complex and complex banks, the latter of which could be seen as holding a further level of risk. We wish to establish how these risk behaviours interact with bank specific, market structure and economic factors. Key results indicate that earnings volatility (business risk) increases with market power but decrease with size and output. While risk-taking (managerial risk) decreases with market power and increases with size and output. Furthermore, in examining return per unit of risk, results demonstrate that increase return and risk-taking is associated with bank specific factors and the economic environment, whereas decreased risk taking is associated with market structure. This suggests a management of risk, which increases around factors under bank control or improving external environment but decreases with the interaction of competitors. Overall, the results suggest that policy should focus on liquidity and equity buffers that should operate countercyclicality but size and market structure per se are not determining factors for higher risk. In terms of the recent financial crisis, it is likely that the great moderation that proceeded it lead to higher risk-taking due to higher economic growth but without the necessary buffers being built up.
\end{abstract}

Keywords: Banks, Risk, Earnings, Volatility, Risk-Return, Complex, Prospect Theory, Market Structure, Sharpe Ratio JEL: C23, G21 


\section{Introduction.}

This paper seeks to examine two aspects of bank risk, with a particular emphasis on how they interact with each other and how this impacts across banks comprised of differing complexity and with the aim of revealing the attendant policy implications. Following the financial crisis, much policy discussion has surrounded bank size and market structure. However, a complete set of empirical evidence regarding bank risk is lacking in which to ensure such policy is informed. The aim and contribution of this paper is to enhance our understanding of bank risk but rather than examine elements of risk isolation, the objective here is to examine the interaction between different components of risk, including business risk and managerial risk as well as bank organisational complexity. The results of this paper should improve the evidence-based environment in which policy is established.

In examining bank risk, first, we model the determinants of earnings volatility with the aim of uncovering the links between volatility and three sets of variables; bank specific factors, market structure and economic activity. While, this approach, which captures business risk, has previously (though not extensively) been considered within the literature, it serves as a base for the remainder of the paper. Second, we examine the relationship between earnings and earnings volatility; that is, the return and risk trade-off. This, therefore, captures management risk and has not been widely considered previously. Again, we are interested in how the three sets of variables (bank specific, market and economic) affect the return-risk trade-off. Having considered these two elements risk separately, we are particularly interested in how they interact, specifically in terms of whether the variables that are associated with an increase or decrease in volatility are the same variables that strengthen or weaken the tradeoff with returns. Moreover, each of these analyses are conducted within the context of separating banks that are considered as complex versus those that are considered as noncomplex with regard to their structure. 
The aim of this paper is to contribute to the debate regarding bank risk and to provide possible policy implications. In particular, volatility provides a proxy for risk, where such risk in turn has implications for economic stability. Thus, knowledge of how bank specific and market structure factors as well as economic performance impact on risk has obvious policy implications. Furthermore, the nature of the relationship between earnings and earnings volatility can lead to inferences about the risk preferences of bank management, which again can lead to policy implications in designing incentives for management. An understanding and examination of such risk is important given the recent crisis period. Furthermore, we separate banks into two risk categories as defined by a complexity indictor assigned to bank holding companies by the Federal Reserve. Again, greater complexity can be regarded as a risk factor. This is of interest as policy discussion usually surrounds only whether banks are large or not rather than more specific detail regarding whether the institutional is complex and the nature of that risk.

While there has been a significant amount of research examining the determinants of bank earnings themselves, there is a relative paucity of studies examining earnings volatility and the relationship between the volatility and mean of earnings. In particular, highly volatile earnings will affect a bank's capital base and could lead to instability in the banking sector (see, for example, Albertazzi and Gambacorta, 2009; Couto, 2002). In turn, a banking system that lacks sufficient stability could impact negatively upon economic growth (e.g., Loayza and Rancière, 2006; Lin and Huang, 2012). While within this context we may be able to infer manager risk-taking behaviour through the relationship between the mean and volatility of earnings. In this respect, therefore, understanding the factors that affect earnings volatility will also contribute to the policy debate following the crisis, for example, regarding bank size and bank market concentration. That is, whether large banks are better able to withstand significant volatility without impact upon their operations and are able to diversify in order to 
reduce volatility (Stever, 2007). Similarly, a concentrated banking system may be less prone to volatility and exhibit greater stability (e.g., Beck et al, 2006; Schaek et al, 2009). Although, an alternative view exists whereby more concentrated banking systems become more fragile (Boyd and De Nicolo, 2005). Further, understanding periods when banks appear to exhibit higher levels of risk, perhaps undertake more risk, when managers of banks are more prone to engage in risk-taking behaviour and whether this differs between banks of differing complexity can enhance the discussion surrounding regulation, governance and incentives for risk (Gonzalez, 2005; Laeven and Levine, 2009).

As noted above, there exists a range of studies that have examined the relationship between various market and bank characteristics and bank earnings, however, there is relatively few that have examined earnings volatility. With regard to the former, a small selection includes Levonian (1993), Roland (1997) and Berger et al (2000) for the US, Goddard et al (2004, 2010) for Europe and Liu and Wilson (2013) for Japan, while, Goddard et al (2013) examine a range of markets. With regard to the literature more closely related to this paper, Boyd and Runkle (1993) argue that there exists a negative relationship between earnings volatility and bank size for US bank holding companies, while Stiroh (2004) argues that no such relationship exists. Most recently, De Haan and Poghosyan (2012a,b) examine the relationship between size and earnings volatility both for commercial banks and bank holding companies. De Haan and Poghosyan (2012a) examining commercial banks argue that there is a negative relationship between bank size and earnings volatility, although the negative relationship is weakened with increased market concentration. This result was based on examining US banks over the relatively short period of 2004-2009. De Haan and Poghosyan (2012b) examining bank holding companies over a period from the mid-1990s also argue that bank size is negatively related to volatility, however, that relationship reverses over a particular size threshold. 
In regards of the relationship between earnings volatility and earnings, this issue has hitherto been overlooked in banking research. From a standard finance perspective, we would expect there to exist a positive relationship between return and volatility (risk). While this is generally accepted within the asset pricing literature, with respect to company behaviour a negative relationship has often been reported, in what has become known as Bowman's paradox (Bowman, 1980). This negative relationship would imply that managers are willing to accept greater risk for a lower reward and has been widely reported (for a review see Nickel and Rodriguez, 2002). The positive relationship between return and volatility (risk) arises from the crucial assumption of risk aversion. That is, investors will only accept higher risk if they are rewarded by a higher (expected) return. However, if we allow managers to exhibit risk-seeking behaviour then a negative relationship between earnings and earnings volatility will exist. Such risk-seeking behaviour would be undesirable from an investors perspective, however, may be desirable for managers depending on their contractual incentives. ${ }^{1}$ While we may not expect mangers to be consistently risk-seeking, it would perhaps be reasonable to assume that there may be periods of time where managers are riskaverse and other periods of time where managers are risk-seeking. Hence, there may exist periods of time where the relationship between return and risk switches between positive and negative. In this vein, the negative relationship can be seen through the application of prospect theory (Kahneman and Tversky, 1979), where managers become risk-seeking following bad outcomes and risk-averse following good outcomes. ${ }^{2}$ From the perspective of the banking sector, an examination of the nature of the return-risk relationship will aid our understanding of the dynamics of risk.

\footnotetext{
${ }^{1}$ Discussions regarding managerial incentives and risk-taking has a long history (e.g., March and Shapira, 1987; Beatty and Zajac, 1994; Wiseman and Gomez-Mejia, 1998), while with reference to banks, see for example, Jeitschko and Jeung, 2005; Chesney et al, 2012).

${ }^{2}$ Evidence of prospect theory has been reported by Fiegenbaum and Thomas (1988) and Johnson (1994).
} 
We begin by examining these two issues separately through standard panel regression approaches. First, modelling the determinants of US bank earnings volatility in a manner broadly similar to that of De Haan and Poghosyan (2012a,b). However, we extend that analysis in three directions. First, we consider a sample period of over twenty-five years as opposed to six (2012a paper) and fifteen (2012b paper). Enhancing the sample period will improve the robustness of the results as it will cover numerous periods of high and low volatility. Second, we include two key additional variables, first, a measure of the market power held by an individual bank through the Lerner index, and second, the economic environment, through GDP growth. In contributing to the discussion regarding large banks and market concentration, both market power and the economic environment in which they operate must also play a role in determining their behaviour. Furthermore, the Lerner index provides a bank level measure and may indicate the degree of contestability within a market that a concentration ratio does not capture. Third, in addition to considering the usual bank specific factors, such as size, we also consider bank type as identified by the complexity indicator. In particular, we are interested in whether risk, as proxied by volatility, exhibits differing dynamics across banks identified as being of different complexity.

Second, we consider the relationship between earning and earnings volatility, again, identifying different categories of bank and volatility measures. Of particular interest is whether there exists a positive or negative relationship and how that relationship may interact with bank, market and economic factors. Notably, we are interested in whether bank size or market structure alters a banks perception of risk or indeed whether it is related to movements in the business cycle. Again, banks are considered according to their complexity indicator as the management of a complex bank may exhibit different risk preferences from one of a less complex bank. Finally, we consider whether there exists any consistency in the factors that affect earnings volatility (bank risk) and risk-taking (managerial risk) and conduct a third 
regression approach based around a Sharpe ratio type measure (returns per unit of risk). Thus, providing a viewpoint of how banks behave with respect to risk and its relationship with returns, including risk adjusted returns. It is hoped that the results here contribute to the policy debate and in particular, whether policy should be applied differently across identified bank types as well as market and economic conditions.

\section{Data and Empirical Methodology.}

We obtain annual data on US Bank Holding Companies from the website of the Federal Reserve Bank of Chicago. The data is obtained over the period from 1986 to 2013. Our key measures of earnings and earnings volatility are based on bank return on assets and return on equity, with volatility determined by the standard deviation of each. ${ }^{3}$ We obtain the standard deviation as a three-year rolling average (a five-year rolling average is also considered for robustness but not reported) based on quarterly data. That is, the annual standard deviation is obtained using observations from the past twelve quarter's. ${ }^{4}$

To examine the determinants of bank earnings volatility and the interactions with earnings in the return-risk analysis, we consider a range of bank, market and economic factors. Notably, we are interested in the effects of bank size, market structure and economic growth. To assess the impact of size on earnings volatility we use (the natural logarithm of) total assets. Market structure is captured in two ways. First, market concentration is captured by the Herfindahl-Hirschman Index (HHI). The HHI measure is calculated as: $H H I=$ $\sum_{i=1}^{N} s_{i}^{2}$, where $s_{i}$ is market share of bank $\mathrm{i}$, and $\mathrm{N}$ is the total number of banks in the industry. Second, market power is captured through the Lerner Index which is calculated as Lerner $_{i t}=\left(\mathrm{P}_{\mathrm{TA} i t}-\mathrm{MC}_{\mathrm{Tai}}\right) / \mathrm{P}_{\mathrm{TA} i t}$, where $\mathrm{P}_{\mathrm{TA} i t}$ is the price of total assets, which is proxied by the ratio of total revenues (interest and non-interest income) to total assets, for bank $i$ at time

\footnotetext{
${ }^{3}$ Results are also available for the variance and absolute deviation but are similar to those reported.

${ }^{4}$ de Haan and Poghosyan (2012b) report results based on four, eight and twelve quarters.
} 
$t$; and $\mathrm{MC}_{\mathrm{TA} i t}$ is the marginal cost of total assets for bank $i$ at time $t .^{5}$ The annual change in GDP is used to capture the effects of economic conditions. As a series of further bank specific characteristics we consider several ratios: market share; equity-to-assets as a measure of leverage; loans-to-assets as a measure of liquidity; non-interest income-to-total income as a measure of diversification; non-interest expenditure-to-total income as a measure of costs; non-performing loans-to-total loans as a measure of loan portfolio risk. Table 1 presents some simple summary statistics.

To model the relationship between earnings volatility and the above identified factors, we consider the following empirical fixed effects panel model specification:

$v_{i, t}=\alpha+\gamma_{i}+\beta_{1} S_{i, t}+\beta_{2} H_{t}+\beta_{3} S_{i, t} x H_{t}+\beta_{4} L_{t}+\beta_{5} S_{i, t} x L_{t}+\theta \Delta y_{t}+\sum_{j=1}{ }^{J} \lambda_{j} X_{j i t}+\varepsilon_{i t}$

where $v$ refers to the measure of volatility for bank $i, \mathrm{~S}$ is the measure of size for bank $i, \mathrm{H}$ is the HHI measure, $\mathrm{L}$ is the Lerner Index, $\Delta y$ is output growth and $x$ contains the bank specific factors. In modelling this equation, it might be expected that larger, more liquid and more diversified banks will be able to absorb shocks better and have lower earnings volatility. In contrast, more levered banks, with higher costs and higher loan risk would have higher volatility. Our expectation would also be that GDP growth would have a counter-cyclical effect on earnings volatility, with greater volatility during economic downturns when macroeconomic risk is also higher.

\footnotetext{
${ }^{5}$ Marginal cost is calculated using the following translog cost function:

$\ln \operatorname{Cost}_{i t}=\beta_{0}+\beta_{1} \ln \mathrm{Q}_{i t}+\frac{\beta_{2}}{2} \ln Q_{i t}^{2}+\beta_{3} \ln \mathrm{W}_{1}+\beta_{4} \ln \mathrm{W}_{2}+\beta_{5} \ln \mathrm{W}_{3}+\beta_{6} \ln \mathrm{Q}_{\mathrm{it}} \ln \mathrm{W}_{1}+\beta_{7} \ln \mathrm{Q}_{\mathrm{it}} \ln \mathrm{W}_{2}+\beta_{8} \ln \mathrm{Q}_{\mathrm{it}} \ln \mathrm{W}_{3}+$ $\beta_{9} \ln \mathrm{W}_{1} \ln \mathrm{W}_{2}+\beta_{10} \ln \mathrm{W}_{1} \ln \mathrm{W}_{3}+\beta_{11} \ln \mathrm{W}_{2} \ln \mathrm{W}_{3}+\beta_{12}$ Trend $+\beta_{13}$ Trend $^{2}+\beta_{14} \ln \mathrm{Q}_{\mathrm{it}}$ Trend $+\beta_{15} \ln \mathrm{W}_{1}$ Trend $+\beta_{16}$ $\ln \mathrm{W}_{2}$ Trend $+\beta_{17} \ln \mathrm{W}_{3}$ Trend $+\varepsilon_{\mathrm{it}}$

where $\mathrm{Q}_{\mathrm{it}}$ is a proxy for bank output (total assets) for bank $i$ at time $t$ and $\mathrm{W}_{\mathrm{k}, \mathrm{it}}$ represent the input prices of labour (ratio of personnel expenses to total assets), funds (ratio of interest expense to total deposits) and fixed capital (ratio of other operating and administrative expenses to total assets), the trend terms are included to capture technical changes in the cost function over time.
} 
To examine the relationship between return and volatility (risk) we consider the following basic equation:

$$
\pi_{i, t}=\alpha+\gamma_{i}+\beta_{1} v_{i, t}+\varepsilon_{i t}
$$

where $\pi$ measures earnings for bank $i$ and again $v$ refers to the measure of volatility. We would ordinarily expect this relationship to be positive, whereby managers would only increase risk if there was an accompanying increase in returns. This assumes that managers risk preferences are characterised by risk-aversion. However, a negative relationship could arise if managers exhibit either risk-seeking behaviour or a behavioural bias such as that described by prospect theory. In this latter case, risk preferences switch between risk-aversion and risk-seeking according to whether current performance is one of either a positive or a negative outcome. More generally, it is conceivable that risk preferences will change with current performance or economic conditions. In light of this last point, therefore, we examine whether the value of beta in equation (2) changes in accordance with the bank, market and economic factors outlined above. Hence, we consider interaction effects between the variables noted in equation (1) and return-risk relationship of equation (2). Thus, we consider whether the principle factors that affect earnings volatility (organisational risk) also affect the relationship between return and risk (managerial risk) and augment equation (2) as such:

$$
\pi_{i, t}=\alpha+\gamma_{i}+\beta_{1} v_{i, t}+\beta_{2} v_{i, t} \times S_{i, t}+\beta_{3} V_{i, t} \times H_{t}+\beta_{4} V_{i, t} \times L_{t}+\beta_{5} V_{i, t} \times y_{t}+\varepsilon_{i t}
$$


where we allow the nature of the relationship between return and risk to vary with size, concentration, market power and output growth. ${ }^{6}$ This will allow us to determine whether managerial risk varies with such systematic factors, with attendant implications for regulation regarding market structure.

In examining the interaction between the bank specific, market and economic factors on both risk (earnings volatility) and the return-risk trade-off, we are able to identify factors that are statistically significant in both regressions (1) and (3). Further to this, we can construct a Sharpe ratio type measure given as earnings dividend by the standard deviation of earnings and thus obtain a measure of return per unit of risk. This Sharpe ratio can then be examined in a regression framework similar to equation (1) as such:

$S_{i, t}=\alpha+\gamma_{i}+\beta_{1} S_{i, t}+\beta_{2} H_{t}+\beta_{3} S_{i, t} x H_{t}+\beta_{4} L_{t}+\beta_{5} S_{i, t} x L_{t}+\theta \Delta y_{t}+\sum_{j=1}{ }^{J} \lambda_{j} x_{j i t}+\varepsilon_{i t}$

where $S$ represents the Sharpe ratio as defined above and the remaining terms remains as defined under equation (1).

In addition, we also categorise our bank holding companies according to their complexity indicator as identified by the Federal Reserve. This complexity indicator identifies bank holding companies that are regarded as non-complex against those that are regarded as complex for a variety of factors. These factors can include the nature of creditextending activities, non-financial factors, high risk activities, management factors and a combination of multiple factors. It is our contention that the degree of volatility and risk will differ between banks regarded as complex and those regarded and not complex. In particular, while we may think that more complex banks will be exposed to greater risk due to their complexity, they are also likely to be larger and more diversified and less exposed to

\footnotetext{
${ }^{6}$ When including interaction terms we need to include the individual terms separately as well. However, for ease of presentation we drop the bank, market and economic factors from the equation and result tables. These are available upon request.
} 
idiosyncratic shocks. Thus, it is possible that such banks will be exposed to less risk. Therefore, we augment the regressions in equations (1), (3) and (4) with a dummy variable that takes the value of one if a bank holding company is identified as complex and zero otherwise. The dummy is introduced both as a level term and an interaction terms thus allowing us to examine whether being designated as complex affects not only the average level of volatility but also how different factors interact with volatility.

\section{Empirical Results.}

\subsection{Modelling Earnings Volatility}

Table 2 reports the results of the earnings volatility model in equation (1) for both the return on assets (ROA) and return on equity (ROE) as the measure of earnings and for both the model that does not include the dummy variable (called Model 1) and the model that does include the dummy variable for complexity (called Model 2). Examining the results across both ROA and ROE we can see that there exists a negative relationship between bank size and earnings volatility. That is, larger banks have a lower level of volatility and hence, risk. This is consistent across both ROA and ROE measures and the two models considered. Furthermore, that the strength of this negative relationship increases with bank holding company complexity (significantly so for the ROA measure). Equally, the relationship between earnings volatility and growth is negative. However, this time the strength of that negative relationship declines with bank complexity (nonetheless, the relationship remains negative). Bank market share, while predominantly exhibiting a negative relationship with earnings volatility, is however, statistically insignificant across the two different measures of volatility and the two models.

With regard to market structure variables, the HHI, which measures market concentration suggests a largely, but not exclusively, positive relationship; however, it is 
insignificant throughout the different modelling approaches. In contrast, the Lerner index, which is a firm-level indication of market power, is statistically significant. Specifically, the Lerner index supports a positive relationship with earnings volatility. Thus, as banks gain more market power (and are able to price mark-up over marginal cost) so the volatility of earnings increases. However, that effect is tempered in two ways, first, through the interaction terms with bank size (although only significantly so for ROA), and second, through the complexity dummy. Thus, larger and more complex bank, which are likely to have greater market power, exhibit only a weak positive relationship with volatility. Finally, the number of banks has a negative relationship with earnings volatility, albeit that the coefficient value is small and statistically insignificant.

Regarding the other variables, we can observe a broadly consistent relationship between the two measures of earnings volatility and GDP growth. GDP growth exhibits a significant negative impact upon earnings volatility. In other words, volatility increases during a recessionary period and declines during an expansionary period. Thus, heightened macroeconomic risk is positively associated with increased bank earnings risk. This relationship remains unchanged by complexity, with the interaction term insignificant. Elsewhere, we can see that a higher equity-to-assets ratio is associated with higher volatility, although is insignificantly lower with complex banks. This suggests that the discipline of higher debt ratios may positively affect risk. Lower liquidity (higher loans-to-assets ratio) increases earnings volatility, although the effect is not significant. Increased bank diversification (higher non-interest income-to-total income) leads to a reduction in volatility, as diversification is intended to do so, although this measure is not significant for ROE volatility. Higher costs (higher non-interest expenditure-to-total income) has a negative effect on volatility, albeit with a small coefficient and limited significance across the different 
measures. Finally, higher loan portfolio risk (higher loan loss provision-to-total loans) increases earnings volatility.

The results presented here suggest that larger banks exhibit lower volatility; arguably such banks will be better able to withstand shocks and is consistent with De Haan and Poghosyan (2012b). In contrast, bank market power increases volatility, this is similar to the result in De Haan and Poghosyan (2012a) for commercial banks (although they exclusively use HHI). This result suggests that banks with market power may take larger risks in lending and investment practise. For example, this result could be seen together with the positive effect on volatility arising from loan portfolio risk. However, it is noticeable that both large and more complex banks exhibit a weaker relationship between market power and volatility. Such banks may recognise their complex character and undertake measures to reduce risk. Indeed, this could be seen as consistent with the result that increased diversification leads to lower volatility. Overall, these results support the view that larger and more diversified banks with lower loan risk can reduce volatility; this will be due to greater diversification of earnings sources and a greater ability to absorb shocks. In addition, these effects are stronger with more complex banks, who perhaps recognise their nature could give rise to additional risk and take steps to reduce it. Furthermore, positive output growth leads to lower volatility and the role of economic conditions cannot be ignored. In terms of policy debate, larger banks per se do not increase volatility, although greater market power does but that is tempered as banks become larger and more complex.

\subsection{Modelling Earnings and Earnings Volatility}

Having examined the factors that affect earnings volatility, we now turn to examine the relationship between earnings and earnings volatility. In particular, standard finance theory based upon risk aversion would suggest that there is a positive relationship between these 
variables (i.e., between return and risk). However, where managers may exhibit risk-taking behaviour either completely or in response to certain factors, for example, in the context of losses according to prospect theory, then that positive relationship may be overturned. Table 3 presents the estimation results of equation (3) above, again both without the complex dummy (Model 1) and with the complex dummy (Model 2) and for both ROA and ROE earnings and volatility. ${ }^{7}$

Evident in Table 3 is that the simple relationship between return and risk is positive, regardless of whether we use ROA or ROE, however, the strength of the relationship is weaker with the ROE measure. It is also noticeable that for complex banks the positive relationship is weaker, suggesting that the level of risk aversion is lower within such banks. To investigate how other bank, market and economic factors interact with the return-risk trade-off we consider the interaction effects. Of notable interest, there are several cases where there is some divergence in the results between complex and non-complex banks. Bank size has a negative influence on the return and risk relationship, however, that affect disappears for complex banks. Similarly, the equity-to-assets ratio has a negative effect on the trade-off but again for complex banks the extent of that relationship is reduced. In the reverse direction, the Lerner index contributes to a positive relationship between return and risk, however, for complex banks that relationship disappears (only for the ROA measure). Elsewhere, we can see that GDP growth, market share and the non-performing loans ratio has a negative impact on the return-risk relationship, while the HHI has a positive effect, regardless of whether banks are identified as complex or not.

These results suggest that, in general, banks are more likely to engage in risk-taking behaviour when economic conditions are good, when they are larger and have a larger market share, when they are less levered, when there is higher risk within their loan portfolio and

\footnotetext{
${ }^{7}$ For brevity in the tables, we only report the volatility and interaction results and not the individual coefficients for each factor, but they are available upon request.
} 
when they have a lower level of liquidity. Such banks may take on greater risk because they feel safer (e.g., positive economic growth, more capital and market share) or they feel the need to increase risk (e.g., because of higher loan portfolio risk and lower liquidity). This last rationale, although not a direct test, does suggest the potential for a prospect theory dynamic, with banks taking on greater risk due to potential losses. Large complex banks are less likely to use a higher capital ratio to take further risk indicating they understand the need to maintain a capital buffer. However, greater market power may lead to increased risk-taking as such banks may feel less threatened by competition.

\subsection{Discussion}

The above sub-sections have examined bank behaviour from two perspectives, examining earnings volatility and the relationship between earnings and earnings volatility. Of course, these two perspectives are likely to be related to each other and thus, we can compare the bank, market and economic characteristics that may provide links between banks that, for example, have higher earnings volatility and a risk-taking disposition.

To that extent, we have seen that higher earnings volatility is typically linked with market power, loan portfolio risk and declining output growth. Lower earnings volatility is typically found with larger and more diversified banks and increasing economic growth. A positive returns-volatility relationship is consistent with greater market power and concentration and decreased GDP. A negative impact on the return-risk relationship arises from increased bank size and market share, a growing economy, and bank risk from decreased liquidity and increased non-performing loans. Therefore, examining those variables that are significant in both regressions, reveals an interesting relationship between the determinants of earnings volatility and the return-risk relation. In other words, between organisational or business risk and managerial risk. Of particular note, those variables 
associated with an increase (decrease) in earnings volatility and also associated with an increase (decrease) in the positive return-risk relationship (e.g., the Lerner index, bank size and GDP growth). In other words, as these variables lead to increased business risk they also lead to an increase in risk-aversion, or a decrease in managerial risk. For example, larger banks exhibit lower earnings volatility but a lower degree of risk aversion, while banks with greater market power exhibit higher volatility but greater risk aversion. Equally, periods characterised by expanding economic growth are consistent with decreasing earnings volatility and increased risk-taking.

These results crucially suggest that risk-taking behaviour by banks is related to both economic conditions and those factors that affect earnings volatility. Simply put, when earnings volatility is higher, banks are more likely to operate in a risk averse way, while when volatility (risk) is lower than bank are more likely to increase risk-taking. This suggests that banks are aware of the environment and the degree of risk in which they operate and adjust risk-taking accordingly. In the context of the financial crisis, the period prior to 2007 was marked with strong economic growth (part of the great moderation), which leads to lower earnings volatility and increased risk-taking. Similarly, over this time banks grew in size and became more diversified. All these factors are linked with lower earnings volatility but greater risk-taking. Furthermore, there are two exceptions to the pattern identified above. First, the equity-to-assets ratio and second, the non-performing loans ratio. In both cases an increase in either ratio leads to both higher volatility (higher business risk) and lower risk aversion (higher managerial risk). This suggests that bank who recognise they have higher loan portfolio risk may also seek risk elsewhere as compensation for the potential losses from loan default. Equally, banks with larger equity ratios, perhaps feel better positioned to absorb shocks, and exhibit greater business and managerial risk. These two factors may also tie risk to prospect theory, where potential losses can lead to greater risk-taking. 


\subsection{Sharpe Ratio}

To examine in greater detail the relationship between the two sets of findings above (i.e., as they relate to earnings volatility and the return/risk relationship) we now consider regressions for a Sharpe ratio variant. Here, we examine the influence on the level of earnings per unit of risk. This allows us to delve further in to the interaction between earnings volatility (an increase in which, all other things remaining constant would reduce the Sharpe ratio) and the risk-taking nature of the bank.

We repeat the regression for earnings volatility as given in equation (1) for the Sharpe ratio and these are reported in Table 4 . However, our key interest is in the interaction between these variables on the Sharpe ratio, earnings volatility and the degree of risk-aversion (risktaking) and so these are summarised in Table 5. Examining Table 4 briefly we can observe a certain amount of similarity between the results for ROA and ROE, albeit with some differences. Of particular note, across both ROA and ROE there is a positive relationship with the market structure variables HHI and the Lerner Index, as well as bank specific loansto-assets ratio and the non-performing loans ratio and GDP growth. It is worth noting that with the exception of GDP growth all of these variables also have a positive effect on earnings volatility, suggesting a proportionately greater increase in profits. A negative relationship with both the ROA and ROE Sharpe ratios can be seen with size, size multiplied by HHI, non-interest income to total income, non-interest expenditure to total income and the number of banks. Of the variables that change sign across the two measures of profit (e.g., growth and market share) it should be noted that they are not statistically significant in at least one model. The obvious exception is for the equity-to-assets ratio. The key difference between ROA and ROE is the inclusion of leverage in the latter and as the equity-to-assets ratio is an inverse measure of leverage it directly affects ROE (which increases with leverage). 
Table 5 presents our key interest in which we can observe the interaction between the Sharpe ratio (profit per unit of risk), earnings volatility (business risk) and the influence on the return-risk trade-off (managerial risk). From this table we can observe an interesting pattern. Assuming all other variables are constant, an increase (decrease) in earnings volatility would lead to a fall (rise) in the Sharpe ratio. We can observe in Table 5 that this inverse pattern rarely occurs. Instead bank profit per unit of risk varies positively with risk. This implies that banks are undertaking action that interact with both the return and risk generating elements. To see this in Table 5, we can look at the columns that indicate whether each factor is related to managers becoming more risk averse or risk taking. Here we can see that risk aversion is associated with market structure variables (HHI and Lerner), while greater risk-taking is associated with economic conditions (GDP growth) or bank specific factors. Hence, greater risk-taking is associated with taking advantage of conducive economic conditions and with factors under bank control. This is an important distinction in how bank behaviour relates to risk. Again, although not a direct test, these results do points towards evidence in favour of prospect theory in managerial behaviour. In particular, we observe an increase in risk-taking behaviour associated with decreases in the Sharpe ratio. Equally, we see an increase in risk-taking associated with higher earnings volatility (except for the market structure related variables).

We repeat the same exercise focussing on complex banks as defined by the dummy. We do not tabulate the results as they are of qualitatively a similar nature. However, we do notice that the strength of these relationships differ between complex and non-complex banks. Of particular note, while most of the variables have a smaller impact on the Sharpe ratio for complex firms the opposite is true for the Lerner Index, GDP growth and the nonperforming loans ratio, all of which have a positive relationship. Furthermore, the Lerner Index itself presents an interesting set of results when comparing non-complex and complex 
banks. For complex banks the Lerner Index is associated with a small positive effect on earnings volatility, has a net zero effect on the return/risk relationship and has a larger positive effect on the Sharpe ratio in comparison to non-complex banks. Again, this indicates that the complexity of a bank does not necessarily mean greater risk.

As we have seen across the sum of the above analysis, market structure itself does not increase risk. In that while they are associated with higher earnings volatility, they equally are associated with higher profit per unit of risk and greater risk-aversion behaviour. Therefore, policy directed at market structure is likely to be misdirected. Instead, regulatory policy should be directed towards ratios relating to leverage and liquidity, which lead to higher earnings volatility and risk-taking (albeit are also associated with a higher Sharpe ratio) and should be designed to operate counter-cyclically to the business cycle. Thus, episodes of risktaking will be counter-acted through the enhancement of buffers against loss.

\section{Summary and Conclusion.}

This paper seeks to examine two key aspects of bank earnings volatility. First, to examine the factors that may help explain earnings volatility and its relationship with bank specific, market and economic variables; that is to examine bank (organisational) risk. Second, to examine the relationship between earnings and earnings volatility from which inferences about risk attitudes can be gleamed; that is to examine managerial risk. Understanding these relationships is important; as volatility can proxy for risk and understanding risk in the banking sector is important for economic stability. Thus, knowing whether specific bank or market characteristics contribute to such risk, or whether wider economic conditions are more important, is crucial in policy-making. Furthermore, being able to infer management behaviour in reference to its attitude to risk is equally important in considering appropriate incentive schemes for bank management or in designing policy to counterweight their 
behaviour. Moreover, the overarching theme is to examine the interaction between these two sources of risk together with a third source which concerns whether banks are described as complex or non-complex by regulators.

We initially consider earnings volatility and the return-risk relationship against a range of bank specific, market structure and economic variables separately. Results suggest that higher volatility is associated with increased market power, higher loan portfolio risk and an economic downturn. Lower volatility is associated with larger banks that are more diversified and is also related to economic expansions. Regarding the relationship between earnings and earnings volatility, a positive relationship is supported by increased market power and market concentration and a reduction in liquidity. A negative relationship occurs with increased bank size and market share, output growth, lower liquidity and higher loan portfolio risk (and to an extent higher equity ratios).

In linking these results from bank (organisational) risk and managerial risk an interesting pattern develops. In general, those factors associated with higher earnings volatility and bank risk (e.g., market concentration and power and an economic contraction) are also associated with a positive return-risk relationship and, hence, lower bank risk. This suggests that managers increase risk-taking when they believe economic circumstances are right (e.g., economic expansion) but reduce risk-taking when faced with market structure considerations. These results are confirmed through a Sharpe ratio analysis, which does highlight a further issue. With respect to bank specific factors surrounding equity buffers, liquidity and loan portfolio risk, these are associated with higher volatility and higher risktaking and, of course, are under the control of managers. These suggest an element of behaviour that is consistent with prospect theory where risk-taking increases with potential losses (through bad loans or lower liquidity). 
In respect of policy, these results suggest that large banks or a concentrated banking sector itself does not increase risk as different risk components offset. In contrast, the results point towards to need for buffers in equity and liquidity to be established and enhanced in a counter-cyclical fashion. Thus, during an economic expansion reserves can be established to counteract the risk-taking associated with higher loan risk and lower liquidity. 


\section{References}

Albertazzi, U and Gambacorta, L (2009), 'Bank profitability and the business cycle', Journal of Financial Stability, 5, 393-409.

Beatty, RP and Zajac, EJ (1994), 'Managerial Incentives, Monitoring, and Risk Bearing: A Study of Executive Compensation, Ownership, and Board Structure in Initial Public Offerings', Administrative Science Quarterly, 39, 313-335.

Beck, T, Demirgüç, A and Levine, R (2006), 'Bank concentration, competition and crises: First results', Journal of Banking and Finance, 30, 1581-1603.

Berger, AN, Bonime, SD, Covitz, DM and Hancock, D (2000), 'Why are bank profits so persistent? The roles of product market competition, information opacity and regional macroeconomic shocks', Journal of Banking and Finance, 24, 1203-1235.

Bowman EA (1980), 'Risk/return paradox for strategic management', $\underline{\text { Sloan Management }}$ Review, Spring, 17-31.

Boyd, JH and De Nicolo, G (2005), 'The theory of bank risk taking and competition revisited', Journal of Finance, 60, 1329-1343.

Boyd, JH and Runkle, DE (1993), 'Size and performance of banking firms: Testing the predictions of theory', Journal of Monetary Economics, 31, 47-67.

Chesney, M, Stromberg, J and Wagner, AF (2012), 'Managerial incentives to take asset risk', National Centre of Competence in Research Financial Valuation and Risk Management, WP \#607, Swiss National Science Foundation.

Couto, R (2002), 'Framework for the assessment of bank earnings', Financial Stability Institute, Bank for International Settlements, Basel.

De Haan, J and Poghosyan, T (2012a), 'Bank size, market concentration, and bank earnings volatility in the US', Journal of International Financial Markets, Institutions and Money, 22, $35-54$.

De Haan, J and Poghosyan, T (2012b), 'Size and earnings volatility of US bank holding companies', Journal of Banking and Finance, 36, 3008-3016.

Fiegenbaum, A and Thomas, H (1988), 'Attitudes towards risk and the risk-return paradox: Prospect theory explanations', Academy of Management Journal', 73, 337-363.

Goddard, J, Molyneux, P and Wilson, JOS (2004), 'The profitability of European banks: A cross-sectional and dynamic panel analysis', Manchester School, 72, 363-381.

Goddard, J, Molyneux, P, Liu, H and Wilson, JOS (2011), 'The persistence of bank profit', Journal of Banking and Finance, 35, 2881-90.

Goddard, J, Molyneux, P, Liu, H and Wilson, JOS (2013), 'Do bank profits converge?', European Financial Management, (forthcoming). 
González, F (2005), 'Bank regulation and risk-taking incentives: An international comparison of bank risk', Journal of Banking and Finance, 29, 1153-1184.

Jeitschko, TD and Jeung, SD (2005), 'Incentives for risk-taking in banking - A unified approach', Journal of Banking and Finance, 29, 759-777.

Johnson, HJ (1994), 'Prospect theory in the commercial banking industry', Journal of Financial and Strategic Decisions, 7, 73-89.

Kahneman, D, and Tversky, A (1979), 'Prospect theory: An analysis of decision under risk', Econometrica, 47, 263-291.

Laeven, L and Levine, R (2009), 'Bank governance, regulation and risk taking', Journal of Financial Economics, 93, 259-275.

Levonian, ME (1993), 'The persistence of bank profits: what the stock market implies', Working Papers in Applied Economic Theory, Number. 93-15. San Francisco, Federal Reserve Bank of San Francisco.

Lin, P-C and Huang, H-C (2012), 'Banking industry volatility and growth', Journal of Macroeconomics, 34, 1007-1019.

Liu, H and Wilson, JOS (2013), 'Competition and risk in Japanese banking', European Journal of Finance, (forthcoming).

Loayza, NV and Rancière, R (2006), 'Financial development, financial fragility and growth', Journal of Money, Credit and Banking, 38, 1051-1076.

March, JG and Shapira, Z (1987), 'Managerial perspectives on risk and risk taking', Management Science, 33, 1404-1418.

Nickel, MN and Rodriquez, MC (2002), 'A review of research on the negative accounting relationship between risk and return: Bowman's paradox', Omega, 30, 1-18.

Roland, KP (1997), 'Profit persistence in large US bank holding companies: an empirical investigation', Office of the Comptroller of Currency Economics Working Paper, No. 97-2.

Schaeck, K, Cihak, M and Wolfe, S (2009), 'Are competitive banking systems more stable?', Journal of Money, Credit and Banking, 41, 711-734.

Stever, R (2007), 'Bank size, credit and the sources of bank market risk', BIS Working Paper \#238, Basel.

Stiroh, KJ (2004), 'Diversification in banking: Is noninterest income the answer?', Journal of Money, Credit, and Banking, 36, 853-882.

Stiroh, KJ and Strahan, PE (2003), 'Competitive dynamics of deregulation: Evidence from U.S. banking', Journal of Money, Credit, and Banking, 35, 801-828. 


\begin{tabular}{|c|c|c|c|c|}
\hline \multicolumn{5}{|c|}{ Table 1. Summary Statistics } \\
\hline & Mean & Median & Std. Dev. & Skew \\
\hline $\mathrm{ROA}$ & 0.007 & 0.005 & 0.023 & 57.511 \\
\hline $\mathrm{ROE}$ & 0.079 & 0.056 & 0.621 & 35.593 \\
\hline ROA - Var. & 0.055 & 0.002 & 0.319 & 77.239 \\
\hline ROE - Var. & 0.392 & 0.032 & 1.489 & 148.963 \\
\hline Size & 13.226 & 12.878 & 1.488 & 1.445 \\
\hline Growth & 0.082 & 0.065 & 0.148 & -1.021 \\
\hline HHI & 0.299 & 0.233 & 0.216 & 1.551 \\
\hline GDP Growth & 0.026 & 0.029 & 0.017 & -1.527 \\
\hline $\mathrm{E} / \mathrm{A}$ & 0.086 & 0.082 & 0.039 & 5.721 \\
\hline $\mathrm{L} / \mathrm{A}$ & 0.623 & 0.636 & 0.136 & -0.699 \\
\hline NII/TI & 0.334 & 0.012 & 5.424 & -80.547 \\
\hline $\mathrm{NIE} / \mathrm{TI}$ & 0.638 & 0.414 & 0.719 & 115.376 \\
\hline NPL/TL & 0.004 & 0.003 & 0.568 & -201.464 \\
\hline \multicolumn{5}{|c|}{$\begin{array}{l}\text { Notes: Variable definitions: ROA is return on assets; ROE is return on equity; Size is the log } \\
\text { of total assets; Growth is the difference of size; HHI is the Herfindahl-Hirschman Index' } \\
\text { GDP Growth is the difference log of GDP; E/A is the equity to assets ratio; L/A is the loans } \\
\text { to assets ratio; NII/TI is the non-interest income to total income ratio; NIE/TI is the non- } \\
\text { interest expenditure to total income ratio; NPL/TL is the non-performing loans to total loans } \\
\text { ratio. }\end{array}$} \\
\hline
\end{tabular}




\begin{tabular}{|c|c|c|c|c|c|c|}
\hline \multicolumn{7}{|c|}{ Table 2. Modelling Earnings Volatility } \\
\hline & \multicolumn{3}{|l|}{ ROA } & \multicolumn{3}{|l|}{ ROE } \\
\hline \multirow[b]{2}{*}{ Variables } & \multirow{2}{*}{$\begin{array}{l}\text { Model } 1 \\
\text { No } \\
\text { Dummy }\end{array}$} & \multicolumn{2}{|l|}{ Model 2} & \multirow{2}{*}{$\begin{array}{l}\text { Model } 1 \\
\text { No } \\
\text { Dummy }\end{array}$} & \multicolumn{2}{|l|}{ Model 2} \\
\hline & & Individual & $\begin{array}{l}\text { x Complex } \\
\text { Dummy }\end{array}$ & & Individual & $\begin{array}{l}\text { x Complex } \\
\text { Dummy }\end{array}$ \\
\hline Constant & $\begin{array}{l}1.656^{*} \\
(10.30)\end{array}$ & $\begin{array}{l}1.163^{*} \\
(6.244)\end{array}$ & $\begin{array}{l}0.964 * \\
(2.49)\end{array}$ & $\begin{array}{l}24.268 \\
(1.72)\end{array}$ & $\begin{array}{l}18.599 \\
(1.13)\end{array}$ & $\begin{array}{l}11.576 \\
(0.34)\end{array}$ \\
\hline Size & $\begin{array}{l}-0.147^{*} \\
(-11.72)\end{array}$ & $\begin{array}{l}-0.011^{*} \\
(-7.54)\end{array}$ & $\begin{array}{l}-0.078^{*} \\
(-2.97)\end{array}$ & $\begin{array}{l}-0.875 \\
(-1.78)\end{array}$ & $\begin{array}{l}-0.348 \\
(-1.27)\end{array}$ & $\begin{array}{l}-1.531 \\
(-0.66)\end{array}$ \\
\hline Growth & $\begin{array}{l}-0.524 * \\
(-16.91)\end{array}$ & $\begin{array}{l}-0.566^{*} \\
(-17.09)\end{array}$ & $\begin{array}{l}0.356^{*} \\
(3.91)\end{array}$ & $\begin{array}{l}-7.241 * \\
(-2.66)\end{array}$ & $\begin{array}{l}-7.714^{*} \\
(-2.64)\end{array}$ & $\begin{array}{l}3.953 \\
(0.49)\end{array}$ \\
\hline Mkt. Sh. & $\begin{array}{l}-0.012 \\
(-0.25)\end{array}$ & $\begin{array}{l}-0.003 \\
(-0.06)\end{array}$ & $\begin{array}{l}-0.167 \\
(-1.58) \\
\end{array}$ & $\begin{array}{l}-1.984 \\
(-0.48)\end{array}$ & $\begin{array}{l}-2.647 \\
(-0.61)\end{array}$ & $\begin{array}{l}3.348 \\
(0.36)\end{array}$ \\
\hline HHI & $\begin{array}{l}0.039 \\
(0.16)\end{array}$ & $\begin{array}{l}0.256 \\
(0.77)\end{array}$ & $\begin{array}{l}-0.574 \\
(-0.89)\end{array}$ & $\begin{array}{l}2.154 \\
(0.10)\end{array}$ & $\begin{array}{l}5.741 \\
(0.20)\end{array}$ & $\begin{array}{l}-2.167 \\
(-0.38)\end{array}$ \\
\hline Size x HHI & $\begin{array}{l}-0.008 \\
(0.48)\end{array}$ & $\begin{array}{l}-0.025 \\
(-1.01)\end{array}$ & $\begin{array}{l}0.042 \\
(0.99)\end{array}$ & $\begin{array}{l}-0.268 \\
(-0.17)\end{array}$ & $\begin{array}{l}-0.526 \\
(-0.24)\end{array}$ & $\begin{array}{l}0.598 \\
(0.72)\end{array}$ \\
\hline Lerner & $\begin{array}{l}6.459^{*} \\
(12.00)\end{array}$ & $\begin{array}{l}9.167^{*} \\
(14.92)\end{array}$ & $\begin{array}{l}-5.883^{*} \\
(-4.00)\end{array}$ & $\begin{array}{l}4.615^{*} \\
(1.99)\end{array}$ & $\begin{array}{l}7.718^{*} \\
(2.38)\end{array}$ & $\begin{array}{l}-0.774 \\
(-1.87)\end{array}$ \\
\hline $\begin{array}{ll}\text { Size } & \mathrm{X} \\
\text { Lerner } & \end{array}$ & $\begin{array}{l}-0.171^{*} \\
(-4.74)\end{array}$ & $\begin{array}{l}-0.379^{*} \\
(-8.35)\end{array}$ & $\begin{array}{l}0.047^{*} \\
(5.04)\end{array}$ & $\begin{array}{l}-0.414 \\
(1.13)\end{array}$ & $\begin{array}{l}-0.966 \\
(-0.49)\end{array}$ & $\begin{array}{l}0.599 \\
(-0.72)\end{array}$ \\
\hline GDP & $\begin{array}{l}-0.006^{*} \\
(-2.30)\end{array}$ & $\begin{array}{l}-0.007^{*} \\
(-2.39)\end{array}$ & $\begin{array}{l}0.001 \\
(0.07)\end{array}$ & $\begin{array}{l}-0.615^{*} \\
(-2.59)\end{array}$ & $\begin{array}{l}-0.654^{*} \\
(-2.62)\end{array}$ & $\begin{array}{l}0.444 \\
(0.52)\end{array}$ \\
\hline $\mathrm{E} / \mathrm{A}$ & $\begin{array}{l}1.469^{*} \\
(6.87)\end{array}$ & $\begin{array}{l}1.496^{*} \\
(6.93)\end{array}$ & $\begin{array}{l}-0.859 \\
(-1.44)\end{array}$ & $\begin{array}{l}3.991 * \\
(7.45)\end{array}$ & $\begin{array}{l}3.995^{*} \\
(7.36)\end{array}$ & $\begin{array}{l}-0.446 \\
(-0.81)\end{array}$ \\
\hline $\mathrm{L} / \mathrm{A}$ & $\begin{array}{l}0.057 \\
(0.98)\end{array}$ & $\begin{array}{l}0.060 \\
(1.00)\end{array}$ & $\begin{array}{l}0.016 \\
(0.09)\end{array}$ & $\begin{array}{l}-1.036 \\
(-0.20)\end{array}$ & $\begin{array}{l}-1.967 \\
(-0.37)\end{array}$ & $\begin{array}{l}0.954 \\
(0.65)\end{array}$ \\
\hline NII/TI & $\begin{array}{l}-0.016^{*} \\
(-6.46)\end{array}$ & $\begin{array}{l}-0.017 * \\
(-6.98)\end{array}$ & $\begin{array}{l}-0.051 \\
(-0.18)\end{array}$ & $\begin{array}{l}-0.009 \\
(-0.44)\end{array}$ & $\begin{array}{l}-0.010 \\
(-0.52)\end{array}$ & $\begin{array}{l}0.003 \\
(0.14)\end{array}$ \\
\hline NIE/TI & $\begin{array}{l}-0.001^{*} \\
(-5.54)\end{array}$ & $\begin{array}{l}-0.001 * \\
(-5.66)\end{array}$ & $\begin{array}{l}-0.001 \\
(-0.36)\end{array}$ & $\begin{array}{l}-0.005 \\
(-0.33)\end{array}$ & $\begin{array}{l}-0.005 \\
(-0.36)\end{array}$ & $\begin{array}{l}0.002 \\
(0.12)\end{array}$ \\
\hline NPL/TL & $\begin{array}{l}4.357^{*} \\
(13.34)\end{array}$ & $\begin{array}{l}4.162 * \\
(12.52)\end{array}$ & $\begin{array}{l}2.997 * \\
(2.35)\end{array}$ & $\begin{array}{l}2.163^{*} \\
(7.54)\end{array}$ & $\begin{array}{l}2.144^{*} \\
(7.33)\end{array}$ & $\begin{array}{l}0.298 \\
(0.27)\end{array}$ \\
\hline No. of Bks & $\begin{array}{l}-0.003 \\
(-1.34)\end{array}$ & $\begin{array}{l}-0.002 \\
(-0.72)\end{array}$ & $\begin{array}{l}0.002 \\
(0.58)\end{array}$ & $\begin{array}{l}-0.061 \\
(-0.36)\end{array}$ & $\begin{array}{l}-0.089 \\
(-0.39)\end{array}$ & $\begin{array}{l}0.096 \\
(0.33)\end{array}$ \\
\hline $\begin{array}{l}\text { Notes: Vari } \\
\text { Holding Co } \\
\text { heterosceda }\end{array}$ & $\begin{array}{l}\text { e defin } \\
\text { anies i } \\
\text { ity and }\end{array}$ & $\begin{array}{l}\text { with } \mathrm{Ta} \\
\text { imple. E } \\
\text { relation }\end{array}$ & $\begin{array}{l}1, \text { in addi } \\
\text { es are coe } \\
\text { arentheses }\end{array}$ & $\begin{array}{l}\text { No. of } \\
\text { ient va }\end{array}$ & $\begin{array}{l}\text { is the nu } \\
\text { ith } t \text {-stati } \\
\text { 1). }\end{array}$ & $\begin{array}{l}\text { ber of Bank } \\
\text { cs robust to }\end{array}$ \\
\hline
\end{tabular}




\begin{tabular}{|c|c|c|c|c|c|c|}
\hline \multicolumn{7}{|c|}{ Table 3. Modelling Earnings and Earnings Volatility } \\
\hline & \multicolumn{3}{|c|}{ ROA } & \multicolumn{3}{|c|}{$\mathrm{ROE}$} \\
\hline \multirow[b]{2}{*}{ Variables } & \multirow{2}{*}{$\begin{array}{l}\text { Model 1 } \\
\text { No } \\
\text { Dummy }\end{array}$} & \multicolumn{2}{|l|}{ Model 2} & \multirow{2}{*}{$\begin{array}{l}\text { Model 1 } \\
\text { No } \\
\text { Dummy }\end{array}$} & \multicolumn{2}{|l|}{ Model 2} \\
\hline & & Individual & $\begin{array}{l}\mathrm{X} \\
\text { Complex } \\
\text { Dummy } \\
\end{array}$ & & Individual & $\begin{array}{l}\mathrm{X} \\
\text { Complex } \\
\text { Dummy }\end{array}$ \\
\hline Volatility & $\begin{array}{l}0.566^{*} \\
(9.87)\end{array}$ & $\begin{array}{l}0.516^{*} \\
(7.52)\end{array}$ & $\begin{array}{l}-0.358^{*} \\
(1.97)\end{array}$ & $\begin{array}{l}0.173 \\
(1.71)\end{array}$ & $\begin{array}{l}0.336 \\
(2.82)\end{array}$ & $\begin{array}{l}-0.557 \\
(-1.57)\end{array}$ \\
\hline Volatility x Size & $\begin{array}{l}-0.024 * \\
(-6.36) \\
\end{array}$ & $\begin{array}{l}-0.025^{*} \\
(-4.23) \\
\end{array}$ & $\begin{array}{l}0.023^{*} \\
(2.22) \\
\end{array}$ & $\begin{array}{l}-0.026 \\
(-3.91)\end{array}$ & $\begin{array}{l}-0.043 \\
(-4.91) \\
\end{array}$ & $\begin{array}{l}0.059 \\
(2.89) \\
\end{array}$ \\
\hline Volatility x HHI & $\begin{array}{l}0.100^{*} \\
(3.15) \\
\end{array}$ & $\begin{array}{l}0.104^{*} \\
(3.11) \\
\end{array}$ & $\begin{array}{l}-0.007 \\
(-0.70) \\
\end{array}$ & $\begin{array}{l}0.107 \\
(2.22) \\
\end{array}$ & $\begin{array}{l}0.112 \\
(2.24) \\
\end{array}$ & $\begin{array}{l}-0.090 \\
(-0.45) \\
\end{array}$ \\
\hline Volatility x Lerner & $\begin{array}{l}1.565^{*} \\
(23.01)\end{array}$ & $\begin{array}{l}1.814 * \\
(24.19)\end{array}$ & $\begin{array}{l}-1.832^{*} \\
(-6.37)\end{array}$ & $\begin{array}{l}-0.191 \\
(-1.55)\end{array}$ & $\begin{array}{l}-0.160 \\
(-1.57)\end{array}$ & $\begin{array}{l}-0.109 \\
(-0.19)\end{array}$ \\
\hline Volatility x GDP Gr. & $\begin{array}{l}-0.014 * \\
(-5.27) \\
\end{array}$ & $\begin{array}{l}-0.013^{*} \\
(4.66)\end{array}$ & $\begin{array}{l}0.001 \\
(0.17) \\
\end{array}$ & $\begin{array}{l}-0.33 \\
(-1.92) \\
\end{array}$ & $\begin{array}{l}-0.054 \\
(-1.85) \\
\end{array}$ & $\begin{array}{l}-0.034 \\
(-1.60) \\
\end{array}$ \\
\hline Volatility x Mkt Share & $\begin{array}{l}-0.066 \\
(-1.94)\end{array}$ & $\begin{array}{l}-0.065 \\
(-1.77)\end{array}$ & $\begin{array}{l}-0.008 \\
(-0.08)\end{array}$ & $\begin{array}{l}0.083 \\
(1.63)\end{array}$ & $\begin{array}{l}0.084 \\
(1.56)\end{array}$ & $\begin{array}{l}-0.062 \\
(-0.36)\end{array}$ \\
\hline Volatility x E/A & $\begin{array}{l}-3.063 * \\
(-15.94)\end{array}$ & $\begin{array}{l}-3.217 * \\
(-16.08)\end{array}$ & $\begin{array}{l}2.549^{*} \\
(3.91)\end{array}$ & $\begin{array}{l}1.265 \\
(4.30)\end{array}$ & $\begin{array}{l}1.394 \\
(4.60)\end{array}$ & $\begin{array}{l}-0.383 \\
(-0.28)\end{array}$ \\
\hline Volatility x NPL/TL & $\begin{array}{l}-3.393 * \\
(-9.72)\end{array}$ & $\begin{array}{l}-3.427 * \\
(-9.55)\end{array}$ & $\begin{array}{l}0.273 \\
(0.23) \\
\end{array}$ & $\begin{array}{l}1.634 \\
(2.68) \\
\end{array}$ & $\begin{array}{l}2.153 \\
(3.43) \\
\end{array}$ & $\begin{array}{l}-8.152 \\
(-3.03) \\
\end{array}$ \\
\hline Volatility x NII/TI & $\begin{array}{l}-0.002 \\
(-0.67)\end{array}$ & $\begin{array}{l}-0.003 \\
(-0.71)\end{array}$ & $\begin{array}{l}0.002 \\
(0.59) \\
\end{array}$ & $\begin{array}{l}-0.004 \\
(-0.85)\end{array}$ & $\begin{array}{l}0.002 \\
(0.43)\end{array}$ & $\begin{array}{l}-0.002 \\
(-0.31)\end{array}$ \\
\hline Volatility x L/A & $\begin{array}{l}-0.189 * \\
(-4.43) \\
\end{array}$ & $\begin{array}{l}-0.173^{*} \\
(3.83)\end{array}$ & $\begin{array}{l}0.076 \\
(0.57) \\
\end{array}$ & $\begin{array}{l}0.082 \\
(1.08)\end{array}$ & $\begin{array}{l}0.128 \\
(1.60)\end{array}$ & $\begin{array}{l}-0.054 \\
(-0.21) \\
\end{array}$ \\
\hline Volatility x NIE/TI & $\begin{array}{l}-0.002 \\
(-0.39)\end{array}$ & $\begin{array}{l}-0.003 \\
(-0.44)\end{array}$ & $\begin{array}{l}0.002 \\
(0.39) \\
\end{array}$ & $\begin{array}{l}-0.008 \\
(-0.19) \\
\end{array}$ & $\begin{array}{l}-0.004 \\
(-0.09) \\
\end{array}$ & $\begin{array}{l}-0.002 \\
(-0.32) \\
\end{array}$ \\
\hline
\end{tabular}




\begin{tabular}{|c|c|c|c|c|c|c|}
\hline \multicolumn{7}{|c|}{ Table 4. Modelling Sharpe Ratio } \\
\hline & \multicolumn{3}{|l|}{ ROA } & \multicolumn{3}{|l|}{ ROE } \\
\hline \multirow[b]{2}{*}{ Variables } & \multirow{2}{*}{$\begin{array}{l}\text { Model } 1 \\
\text { No } \\
\text { Dummy }\end{array}$} & \multicolumn{2}{|l|}{ Model 2} & \multirow{2}{*}{$\begin{array}{l}\text { Model 1 } \\
\text { No } \\
\text { Dummy }\end{array}$} & \multicolumn{2}{|l|}{ Model 2} \\
\hline & & Individual & $\begin{array}{l}\text { x Complex } \\
\text { Dummy }\end{array}$ & & Individual & $\begin{array}{l}\text { x Complex } \\
\text { Dummy }\end{array}$ \\
\hline Constant & $\begin{array}{l}-0.905^{*} \\
(-8.48)\end{array}$ & $\begin{array}{l}-0.352 * \\
(-2.81)\end{array}$ & $\begin{array}{l}-0.944^{*} \\
(-3.54)\end{array}$ & $\begin{array}{l}0.362 \\
(1.82)\end{array}$ & $\begin{array}{l}0.895^{*} \\
(3.82)\end{array}$ & $\begin{array}{l}-1.371^{*} \\
(-2.76)\end{array}$ \\
\hline Size & $\begin{array}{l}-0.016^{*} \\
(1.97)\end{array}$ & $\begin{array}{l}-0.063 * \\
(-6.41)\end{array}$ & $\begin{array}{l}0.061 * \\
(3.37)\end{array}$ & $\begin{array}{l}-0.066^{*} \\
(-4.23)\end{array}$ & $\begin{array}{l}-0.112 * \\
(-6.11)\end{array}$ & $\begin{array}{l}0.103 * \\
(3.07)\end{array}$ \\
\hline Growth & $\begin{array}{l}-0.258^{*} \\
(-12.85)\end{array}$ & \begin{tabular}{|c|}
$-0.236^{*}$ \\
$(-10.94)$
\end{tabular} & $\begin{array}{l}0.169^{*} \\
(2.86)\end{array}$ & $\begin{array}{l}0.056 \\
(1.49)\end{array}$ & $\begin{array}{l}0.106^{*} \\
(2.62)\end{array}$ & $\begin{array}{l}-0.085 \\
(-0.77)\end{array}$ \\
\hline Mkt. Sh. & $\begin{array}{l}0.004 \\
(0.12)\end{array}$ & $\begin{array}{l}-0.013 \\
(-0.40)\end{array}$ & $\begin{array}{l}-0.152 * \\
(-2.17)\end{array}$ & $\begin{array}{l}-0.057 \\
(-0.99)\end{array}$ & $\begin{array}{l}-0.063 \\
(-1.01)\end{array}$ & $\begin{array}{l}-0.135 \\
(-1.03)\end{array}$ \\
\hline HHI & $\begin{array}{l}0.907 * \\
(5.69)\end{array}$ & $\begin{array}{l}1.505^{*} \\
(6.70)\end{array}$ & $\begin{array}{l}-0.983^{*} \\
(-3.54)\end{array}$ & $\begin{array}{l}0.447 \\
(1.50)\end{array}$ & $\begin{array}{l}0.785 \\
(1.88)\end{array}$ & $\begin{array}{l}-0.058 \\
(-0.07)\end{array}$ \\
\hline Size x HHI & $\begin{array}{l}-0.078^{*} \\
(-6.70)\end{array}$ & $\begin{array}{l}-0.127 * \\
(-7.58)\end{array}$ & $\begin{array}{l}0.088^{*} \\
(3.11)\end{array}$ & $\begin{array}{l}-0.043^{*} \\
(-1.98)\end{array}$ & $\begin{array}{l}-0.071 * \\
(-2.27)\end{array}$ & $\begin{array}{l}0.023 \\
(0.43)\end{array}$ \\
\hline Lerner & $\begin{array}{l}4.757^{*} \\
(14.08)\end{array}$ & \begin{tabular}{|l|}
$5.123^{*}$ \\
$(12.28)$
\end{tabular} & $\begin{array}{l}7.066^{*} \\
(6.52)\end{array}$ & $\begin{array}{l}2.612^{*} \\
(4.15)\end{array}$ & $\begin{array}{l}3.174 * \\
(4.08)\end{array}$ & $\begin{array}{l}7.112^{*} \\
(3.52)\end{array}$ \\
\hline $\begin{array}{ll}\text { Size } & \mathrm{x} \\
\text { Lerner } & \end{array}$ & $\begin{array}{l}0.131^{*} \\
(5.35)\end{array}$ & \begin{tabular}{|l|}
$0.099 *$ \\
$(3.23)$
\end{tabular} & $\begin{array}{l}-0.360 * \\
(-5.18)\end{array}$ & $\begin{array}{l}0.191^{*} \\
(4.17)\end{array}$ & $\begin{array}{l}0.145^{*} \\
(2.51)\end{array}$ & $\begin{array}{l}-0.372^{*} \\
(-2.87)\end{array}$ \\
\hline GDP & $\begin{array}{l}0.020^{*} \\
(11.41)\end{array}$ & $\begin{array}{l}0.012 * \\
(6.96)\end{array}$ & $\begin{array}{l}0.023^{*} \\
(3.63)\end{array}$ & $\begin{array}{l}0.049^{*} \\
(15.10)\end{array}$ & $\begin{array}{l}0.042^{*} \\
(12.39)\end{array}$ & $\begin{array}{l}0.020 \\
(1.71)\end{array}$ \\
\hline $\mathrm{E} / \mathrm{A}$ & $\begin{array}{l}2.481 * \\
(17.61)\end{array}$ & $\begin{array}{l}2.475^{*} \\
(17.35)\end{array}$ & $\begin{array}{l}-1.782^{*} \\
(-4.60)\end{array}$ & $\begin{array}{l}-3.669 * \\
(-13.98)\end{array}$ & $\begin{array}{l}-3.666^{*} \\
(-13.78)\end{array}$ & $\begin{array}{l}-1.932^{*} \\
(-2.67)\end{array}$ \\
\hline $\mathrm{L} / \mathrm{A}$ & $\begin{array}{l}0.679 * \\
(17.57)\end{array}$ & \begin{tabular}{|l|}
$0.692^{*}$ \\
$(17.32)$
\end{tabular} & $\begin{array}{l}-0.137 \\
(-1.25)\end{array}$ & $\begin{array}{l}0.626^{*} \\
(8.70)\end{array}$ & $\begin{array}{l}0.661 * \\
(8.87)\end{array}$ & $\begin{array}{l}-0.305 \\
(-1.49)\end{array}$ \\
\hline NII/TI & $\begin{array}{l}-0.003^{*} \\
(2.15)\end{array}$ & $\begin{array}{l}-0.003^{*} \\
(1.96)\end{array}$ & $\begin{array}{l}0.001 \\
(0.42)\end{array}$ & $\begin{array}{l}-0.001 \\
(-0.38)\end{array}$ & $\begin{array}{l}-0.001 \\
(-0.43)\end{array}$ & $\begin{array}{l}0.001 \\
(0.36)\end{array}$ \\
\hline NIE/TI & $\begin{array}{l}-0.002^{*} \\
(-2.00)\end{array}$ & \begin{tabular}{|l|}
-0.001 \\
$(-1.61)$
\end{tabular} & $\begin{array}{l}0.001 \\
(0.35)\end{array}$ & $\begin{array}{l}-0.003 \\
(-0.15)\end{array}$ & $\begin{array}{l}-0.005 \\
(-0.03)\end{array}$ & $\begin{array}{l}0.001 \\
(0.32)\end{array}$ \\
\hline NPL/TL & $\begin{array}{l}4.642^{*} \\
(21.97)\end{array}$ & $\begin{array}{l}4.215^{*} \\
(19.59)\end{array}$ & $\begin{array}{l}5.237 * \\
(6.27)\end{array}$ & $\begin{array}{l}0.619 \\
(1.57)\end{array}$ & $\begin{array}{l}0.433 \\
(1.08)\end{array}$ & $\begin{array}{l}1.014 \\
(0.65)\end{array}$ \\
\hline No. of Bks & $\begin{array}{l}-0.005^{*} \\
(4.15)\end{array}$ & $\begin{array}{l}0.003 \\
(1.70)\end{array}$ & $\begin{array}{l}-0.010 * \\
(-4.73)\end{array}$ & $\begin{array}{l}-0.001 \\
(-0.38)\end{array}$ & $\begin{array}{l}0.007 * \\
(2.07)\end{array}$ & $\begin{array}{l}-0.010^{*} \\
(-2.46)\end{array}$ \\
\hline $\begin{array}{l}\text { Notes: Vari } \\
\text { Holding Co } \\
\text { heterosceda }\end{array}$ & $\begin{array}{l}\text { defini } \\
\text { anies i } \\
\text { ity and }\end{array}$ & $\begin{array}{l}\text { s with T } \\
\text { ample. I }\end{array}$ & $\begin{array}{l}1, \text { in addi } \\
\text { es are coe } \\
\text { arentheses }\end{array}$ & $\begin{array}{l}\text { No. of } \\
\text { ient va }\end{array}$ & $\begin{array}{l}\text { s is the nu } \\
\text { vith } t \text {-stati } \\
\text { (1). }\end{array}$ & $\begin{array}{l}\text { ber of Bank } \\
\text { cs robust to }\end{array}$ \\
\hline
\end{tabular}




\begin{tabular}{|c|c|c|c|c|c|}
\hline \multirow{2}{*}{\multicolumn{6}{|c|}{$\begin{array}{r}\begin{array}{r}\text { Table 5. Summary of Relationship with Sharpe } \\
\text { and Return-Risk Trade- }\end{array} \\
\text { Return on Assets } \\
\end{array}$}} \\
\hline & & & & & \\
\hline \multicolumn{3}{|c|}{ Sharpe Ratio Increase } & \multicolumn{3}{|c|}{ Sharpe Ratio Decrease } \\
\hline Variable & Earns Vol. & Ret-Risk & Variable & Earns Vol & Ret-Risk \\
\hline Mkt Share & Neg & RT & Size & Neg & RT \\
\hline HHI & Pos & RA & Growth & $\mathrm{Neg}$ & - \\
\hline Lerner & Pos & RA & SizexHHI & $\mathrm{Neg}$ & - \\
\hline SizexLerner & Neg & - & NII/TI & $\mathrm{Neg}$ & RT \\
\hline GDP & Neg & RT & NIE/TI & $\mathrm{Neg}$ & - \\
\hline EA & Pos & RT & No. of Bks & $\mathrm{Neg}$ & RT \\
\hline LA & Pos & RT & & & \\
\hline NPL & Pos & RT & & & \\
\hline \multicolumn{6}{|c|}{ Return on Equity } \\
\hline Growth & Neg & - & Size & $\mathrm{Neg}$ & RT \\
\hline HHI & Pos & RA & Mkt Share & $\mathrm{Neg}$ & RA \\
\hline Lerner & Pos & RT & SizexHHI & $\mathrm{Neg}$ & - \\
\hline SizexLerner & Neg & - & EA & Pos & RA \\
\hline GDP & Neg & RT & NII/TI & $\mathrm{Neg}$ & RT \\
\hline LA & $\mathrm{Neg}$ & RA & NIE/TI & $\mathrm{Neg}$ & - \\
\hline NPL & Pos & RA & No. of Bks & $\mathrm{Neg}$ & RT \\
\hline \multicolumn{6}{|c|}{$\begin{array}{l}\text { Notes: Table summarises the relationship between variables that cause the Sharpe Ratio to } \\
\text { increase or decrease together with whether the variables are also associated with Pos(itive) or } \\
\text { Neg(ative) effect on Earnings Volatility and with an increase (RA; risk averse) in the positive } \\
\text { return-risk trade-off or a decrease (RT; risk taking). }\end{array}$} \\
\hline
\end{tabular}

